\title{
Transmission, In Planta Distribution, and Management of Hibiscus latent Fort Pierce virus, a Novel Tobamovirus Isolated from Florida Hibiscus
}

\author{
Ivanka Kamenova and Scott Adkins, United States Department of Agriculture, Agricultural Research Service, \\ United States Horticultural Research Laboratory, 2001 South Rock Road, Fort Pierce, FL 34945, USA
}

\begin{abstract}
Kamenova, I., and Adkins, S. 2004. Transmission, in planta distribution, and management of Hibiscus latent Fort Pierce virus, a novel tobamovirus isolated from Florida hibiscus. Plant Dis. 88:674-679.

Three aspects of the infection process of a new tobamovirus species, Hibiscus latent Fort Pierce virus, recently isolated from hibiscus in Florida, were examined: (i) transmission efficiency of rub-, slash-, and cut-inoculation for two hibiscus cultivars, Pink Versicolor and Brilliant Red; (ii) distribution within infected hibiscus plants; and (iii) treatments to prevent infection during plant propagation and pruning. Rub-, slash-, and cut-inoculation methods were all effective and yielded infection rates of 66, 74, and 70\%, respectively, in Pink Versicolor and 50, 56, and 38\%, respectively, in Brilliant Red. Analysis of virus distribution in infected plants over time revealed that the virus moved from the place of inoculation to the roots and then toward the bottom (oldest) leaves of the plants. Virus was found in all leaves on branches of Brilliant Red plants at 210 days postinoculation, whereas it remained restricted to the bottom and middle leaves of Pink Versicolor plants at 290 days postinoculation. Although several treatments of tools reduced infection of hibiscus during experiments mimicking plant propagation and pruning, 10\% (wt/vol) sodium hypochlorite and $20 \%$ (wt/vol) nonfat dry milk completely prevented infection.
\end{abstract}

A new tobamovirus species has been recently isolated from hibiscus (Hibiscus rosa-sinensis) in Florida (1). This Florida hibiscus virus has been given the name Hibiscus latent Fort Pierce virus (HLFPV) to reflect the site (Fort Pierce, FL) and host (hibiscus) from which it was originally isolated. A limited survey has revealed that this virus is widespread in hibiscus and related species in the Florida landscape (1).

Hibiscus plants are common ornamentals in Florida and other subtropical and tropical areas. They are widely used for hedges due to their dense growth and attractive flowers. Hibiscus is vegetatively propagated by cuttings in warm climates and shipped to different regions for indoor and outdoor use (17). This horticultural practice is also a very effective method for virus transmission and dissemination. Cuttings from virus-infected stock plants lead to the production and ultimately dissemination of more infected plants. Several methods for detection of HLFPV have been compared and tested for usefulness in hibiscus stock plant indexing to reduce the

Corresponding author: Scott Adkins

E-mail: SAdkins@ushrl.ars.usda.gov

Accepted for publication 13 February 2004.

Publication no. D-2004-0408-01R

This article is in the public domain and not copyrightable. It may be freely reprinted with customary crediting of the source. The American Phytopathological Society, 2004. propagation of plants infected with HLFPV (16).

Because HLFPV is a newly recognized virus of hibiscus, little information is available regarding its transmission during vegetative propagation and pruning, or its overall distribution in infected plants. In general, viruses spread by two paths in infected plants: (i) cell-to-cell through the plasmodesmata and (ii) long-distance through the vascular tissues (15). Based upon the results of his experiments with Tobacco mosaic virus (TMV) in tomato, Samuel suggested that viruses follow certain routes of movement in plants (21). He demonstrated that from the initial place of infection, TMV moved first to the roots, and then to the young, apical leaves before infecting the middle-aged and older leaves. Although it is often assumed that viruses that systemically infect plant hosts eventually become evenly distributed throughout the plant, this rarely happens (15). For many viruses infecting woody perennials, including Plum pox virus (PPV), Tomato ringspot virus (ToRSV), Citrus ringspot virus (CRSV), Apple chlorotic leaf spot virus (ACLSV), and Prunus necrotic ringspot virus (PNRSV), erratic and irregular distribution patterns have been observed $(2,4,7,11,20,22)$.

In the present report, three aspects of HLFPV infection of hibiscus were studied: (i) the efficiency of rub-, slash-, and cutinoculation methods for its transmission to two commercial hibiscus cultivars; (ii) the general pattern of virus distribution and accumulation within infected plants; and (iii) the ability of different treatments to prevent transmission with contaminated tools during plant propagation and pruning. Results of these studies reveal several features of the pathosystem that will ultimately guide management strategies.

\section{MATERIALS AND METHODS}

Plant material. Plants from two hibiscus cultivars, Pink Versicolor and Brilliant Red, were used in all experiments. One plant per 1-gal pot was grown in steamed Fafard 4P (Conrad Fafard, Inc., Adawam, MA) soilless growing medium. Leaf and root samples from all plants were tested by double antibody sandwich enzyme-linked immunosorbent assay (DAS-ELISA) for the presence of HLFPV as previously described $(1,16)$ prior to their use. Briefly, the plates were coated with rabbit polyclonal $\operatorname{IgG}(100 \mu \mathrm{l}$ of $1 \mu \mathrm{g} / \mathrm{ml}$ per well $)$ diluted in $0.05 \mathrm{M}$ sodium carbonate buffer (pH 9.6). Tissue was homogenized at a ratio of 1:25 (wt/vol) in sample buffer consisting of phosphate-buffered saline (PBS; $0.14 \mathrm{M} \mathrm{NaCl}, 1 \mathrm{mM} \mathrm{KH} \mathrm{PO}_{4}, 8 \mathrm{mM}$ $\left.\mathrm{Na}_{2} \mathrm{HPO}_{4}, 2.5 \mathrm{mM} \mathrm{KCl}[\mathrm{pH} 7.4]\right)$ containing $0.5 \%$ (vol $/ \mathrm{vol})$ Tween $20,2 \%$ (wt/vol) polyvinylpyrrolidone, and $0.2 \%$ (wt/vol) ovalbumin. Homogenate $(100 \mu \mathrm{l}$ per well) was incubated overnight at $4^{\circ} \mathrm{C}$ followed by conjugated $\operatorname{IgG}(1: 1,000$ dilution in sample buffer, $100 \mu \mathrm{l}$ per well) with incubation for $3 \mathrm{~h}$ at $37^{\circ} \mathrm{C}$. Plates were washed three times with PBST between each step. Controls of sample buffer only, uninfected leaves, and infected leaves were included in all assays. Absorbance at $405 \mathrm{~nm}$ was measured with an MRX Revelation microplate reader (Thermo Labsystems, Chantilly, VA) about 60 to 90 min after the addition of the substrate ( $p$-nitrophenyl phosphate). Samples with readings of $A_{405 \mathrm{~nm}}>0.1$ were considered positive, a reading which was always a minimum of four to five times the mean absorbance of uninfected leaves.

Inoculation techniques. Fifty Pink Versicolor and 32 Brilliant Red hibiscus (all with a single stem, 3 months old, and $~ 30$ $\mathrm{cm}$ high) were each inoculated by one of three methods: rubbing, slashing, or cutting. Inoculum for all experiments consisted of partially purified HLFPV (1) at a concentration of $2 \mu \mathrm{g} / \mathrm{ml}$. For rubinoculation, the inoculum was applied on the upper surface of two adjacent leaves (leaves 3 and 4 in Figs. 1 and 2) using a cotton swab. The leaves were dusted with 
Carborundum prior to and rinsed with tap water after inoculation. For slashinoculation, the middle section of a plant stem was slashed four times using a viruscontaminated scalpel. The scalpel was dipped $(\sim 10 \mathrm{~s})$ in inoculum before each slash. Cut-inoculation was designed to mimic pruning and plant propagation. The upper one-third of each plant stem was excised using a scalpel dipped $(\sim 10 \mathrm{~s})$ in inoculum. Twenty of the excised stems of Pink Versicolor were dipped in a commercially available auxin (Rootone, Green Light Co., San Antonio, TX), rooted in Fafard 4P, and later tested by DAS-ELISA for virus presence. Plants used as mockinoculated controls were treated only with buffer. Chenopodium quinoa, a local lesion indicator host for HLFPV (1), was used to assay inoculum infectivity. Inoculated plants were maintained in an airconditioned greenhouse under natural lighting with a daytime high temperature of $30^{\circ} \mathrm{C}$ and insect control.

Virus distribution and detection methods. To study HLFPV distribution and accumulation in inoculated plants, samples of leaves, roots, and bark were collected and tested at various days postinoculation (dpi). All leaf samples were collected with a one-hole paper punch, which allowed nondestructive leaf sampling (usually two to three "punches" per leaf per time). Rub-inoculated leaves (leaves 3 and 4) were tested at 5 and 10 dpi, followed by testing of all leaves on the plants at 20, 45, and 75 dpi. All leaves of slash- and cut-inoculated plants were tested at the same intervals $(20,45$, and 75 dpi). Plants were pruned following the 75dpi sampling, allowed to flush, and sampled at 120, 160, 210, and 290 dpi. Root samples were collected from the main feeder roots at 10, 20, and 40 dpi. Bark samples were obtained by cutting small strips from the main branch of the plant using a scalpel. Before each sampling, the scalpel was swabbed in undiluted swimming pool chlorine $(10 \%$ [wt/vol] sodium hypochlorite $[\mathrm{NaOCl}])$, rinsed twice with water, and dried between sheets of paper.

All assessments of virus infection and distribution in inoculated plants were made by DAS-ELISA as described above. Additionally, tissue blot immunoassay (TBIA) and immunocapture reverse transcriptionpolymerase chain reaction (IC-RT-PCR) were used as previously described (16) to compare virus distribution in selected plants of both cultivars.

Environmental effect on virus distribution. To determine how environmental conditions (especially temperature and light) affected HLFPV distribution and accumulation, infected plants of both cultivars were divided into three groups, which were grown at different locations. Thirty Pink Versicolor and 16 Brilliant Red plants remained under natural light in the greenhouse at $30^{\circ} \mathrm{C}$. Thirty Pink Versicolor and
17 Brilliant Red plants were moved to a growth chamber with a photoperiod of 12 $\mathrm{h}$ provided by a mixture of high pressure sodium and metal halide lights $\left(300 \mu \mathrm{E} \mathrm{m}^{-2}\right.$ $\mathrm{s}^{-1}$ ) at $20^{\circ} \mathrm{C}$. Sixteen Pink Versicolor and 13 Brilliant Red plants were transplanted to the field in November 2002, grown for 3 months at an average temperature of $16^{\circ} \mathrm{C}$, and then tested. Over 4 months, the greenhouse and growth chamber plants were pruned once (after 120-dpi testing) and tested twice.

Sanitation. Chemical treatments with 3 or $6 \%(\mathrm{vol} / \mathrm{vol}) \mathrm{NaOCl}$ (household bleach), 10 or $20 \%$ (wt/vol) trisodium phosphate (TSP), and 1 or $2 \%$ (wt/vol) sodium hydroxide $(\mathrm{NaOH})$ were evaluated for their ability to prevent infection of 44 Pink Versicolor plants during propagation with contaminated pruning tools. A scalpel was contaminated with partially purified HLFPV (at a concentration of $2 \mu \mathrm{g} / \mathrm{ml}$ ), dipped $(\sim 10 \mathrm{~s})$ in one of the above solutions, and immediately used to excise the upper portion of single-stemmed plants as in the prior cut-inoculations. Controls consisted of five plants cut with sterile scalpels and five plants cut with contaminated but untreated scalpels.

A second sanitation test was made with 128 Pink Versicolor plants, increased concentrations of the same and additional chemicals, and an increase of treatment time $(1 \mathrm{~min})$ of contaminated tools. Following contamination as above, scalpels were soaked for $1 \mathrm{~min}$ in $10 \%$ (wt/vol) $\mathrm{NaOCl}, 20 \%$ (wt/vol) TSP, 20\% (wt/vol) nonfat dry milk (NFDM), 5\% (wt/vol) $\mathrm{NaOH}$, or $90 \%$ (vol/vol) ethanol, or heated in the flame of a plumber's propane torch. Controls consisted of 10 plants cut with contaminated but untreated scalpels and 15 plants cut with contaminated scalpels soaked for $1 \mathrm{~min}$ in tap water prior to use. Leaves and roots of plants from both experiments were assayed by DAS-ELISA at 45 dpi.

\section{RESULTS}

Efficiency of inoculation techniques. The efficiency of each inoculation method was determined from summarized DASELISA results of HLFPV presence in roots and leaves of inoculated plants. More Pink Versicolor than Brilliant Red plants became infected with each inoculation method. Transmission rates of 66, 74, and $70 \%$ by rub-, slash-, and cut-inoculations, respectively, were recorded for Pink Versi- color; whereas for Brilliant Red these rates were 50, 56, and $38 \%$. All 20 of the excised Pink Versicolor stem tips (from the cut-inoculation experiments) rooted, and $60 \%$ were positive for the virus by DASELISA. All mock-inoculated control plants (10 Pink Versicolor and 9 Brilliant Red) remained negative for the virus throughout the experiment.

Virus distribution. Virus distribution and accumulation in leaves from different positions along the branch, roots, and bark of inoculated plants were examined at specific dpi. Inoculated leaves of both cultivars in the rub-inoculation experiment were tested by DAS-ELISA at $5 \mathrm{dpi}$. HLFPV was detected in 5 of 50 Pink Versicolor and 15 of 32 Brilliant Red plants. Virus was not detected in inoculated leaves of Pink Versicolor plants at $10 \mathrm{dpi}$, whereas 3 Brilliant Red plants were still positive at $10 \mathrm{dpi}$. At these times (5 and 10 dpi), the leaves adjacent to the inoculated leaves, or the slashes or cuts (in slash- and cut-inoculated plants, respectively) of both cultivars tested negative for the virus.

HLFPV moved rapidly from the initial place of inoculation to the roots of the plants from both cultivars. Since we observed no difference in virus distribution based on inoculation method, the results for virus presence in the roots of the plants from the three inoculation methods were pooled (Table 1). The virus was detected in one-third of all inoculated plants of Pink Versicolor at $10 \mathrm{dpi}\left(A_{405} \mathrm{~nm}\right.$ readings of infected plants ranged from 0.147 to 1.061). At $10 \mathrm{dpi}$, only slash-inoculated plants from Brilliant Red were tested, and approximately one-third of the plants were positive $\left(A_{405 \mathrm{~nm}}\right.$ readings in infected plants ranged from 0.123 to 0.537 ). Uninfected plants from both cultivars produced $A_{405} \mathrm{~nm}$ readings of 0.004 to 0.027 . The number of plants with roots testing positive by DASELISA increased for both cultivars at each subsequent analysis, and at the end of the test (40 dpi), 69\% of Pink Versicolor and $48 \%$ of Brilliant Red plants were infected.

Virus accumulation and distribution in leaves from the bottom (the lowest three to four leaves), middle (the next three to four leaves), and top (next two to three not fully expanded leaves) sections of branches from Pink Versicolor and Brilliant Red were analyzed by DAS-ELISA at different dpi (Table 2). At $20 \mathrm{dpi}$, the virus was detected in the roots and the oldest (bottom) leaves but not in the youngest (top)

Table 1. Presence of Hibiscus latent Fort Pierce virus in roots of rub-, slash-, and cut-inoculated hibiscus plants at defined days postinoculation (dpi) as determined by double antibody sandwich enzyme-linked immunosorbent assay (DAS-ELISA)

\begin{tabular}{lccc}
\hline & \multicolumn{3}{c}{ dpi } \\
\cline { 2 - 4 } Cultivar & $\mathbf{1 0}$ & $\mathbf{2 0}$ & $\mathbf{4 0}$ \\
\hline Pink Versicolor & $50 / 150^{\mathrm{a}}$ & $73 / 150$ & $104 / 150$ \\
Brilliant Red & $12 / 32$ & $43 / 96$ & $46 / 96$ \\
\hline
\end{tabular}

${ }^{a}$ Number of plants positive in roots by DAS-ELISA/total number of tested plants. 
leaves of the plants of both cultivars. The virus was detected in the middle leaves of a few (five) plants from both cultivars. The numbers of plants from both cultivars with detectable virus in bottom leaves increased at 45 and 75 dpi. Unlike Pink Versicolor plants, several Brilliant Red plants had virus present in the top leaves at 45 and 75 dpi.

To examine the effect of pruning on virus movement and distribution, all plants were pruned after the 75-dpi sampling, and the new flush was tested at 120 dpi. HLFPV was detected in the leaves from the bottom part of plant branches of 14 Pink Versicolor plants that were negative at 75 dpi. However, the bottom leaves of seven Pink Versicolor plants that were positive at 75 dpi were negative after pruning when tested at $120 \mathrm{dpi}$. The number of Brilliant Red plants with virus in the bottom leaves increased after pruning. In general, the overall pattern of virus distribution in the leaves of infected plants of the two cultivars was consistent relative to virus presence in the leaves at different positions along the branch before and after pruning. No upward movement to the leaves of the top part of branches of Pink Versicolor plants was recorded, and the virus was localized in the bottom leaves, except for a few plants with virus in the leaves from the middle part of the branches. As before pruning, virus was also present in the top leaves of several Brilliant Red plants.

It should be noted also that HLFPV was not persistently detected in the leaves of infected, root-positive Pink Versicolor plants during time course analyses. For example, five plants were leaf positive by DAS-ELISA at 45 and 120 dpi but not at 75 dpi. Leaves of seven more plants were positive at 75 dpi but negative later at 120 dpi (after pruning), indicating some temporal variations in virus concentrations. Virus was detected in the leaves of some Pink Versicolor plants at only one sampling time, and in other Pink Versicolor plants at each sampling time. The same slow and restricted virus distribution observed in Pink Versicolor plants was also found in excised and rooted cuttings (cutinoculation experiment) from the same cultivar. Virus was detected in the roots of 12 , but in the bottom leaves of only six of the same 12 cuttings at $45 \mathrm{dpi}$, with no change in this distribution through $120 \mathrm{dpi}$.

Environmental effect on virus distribution. A difference in virus distribution was observed between the plants grown at different conditions with both cultivars (Table 3). In general, the virus was distributed more widely (detected in more leaves from different sections of the plant) in growth chamber- (Pink Versicolor and

Table 2. Distribution of Hibiscus latent Fort Pierce virus in leaves of rub-, slash-, and cut-inoculated hibiscus plants at defined days postinoculation (dpi) as determined by double antibody sandwich enzyme-linked immunosorbent assay (DAS-ELISA)

\begin{tabular}{lllllllll}
\hline & \multicolumn{3}{c}{ Pink Versicolor } & & \multicolumn{3}{c}{ Brilliant Red } \\
\cline { 2 - 3 } \cline { 7 - 8 } dpi & $\mathbf{B}^{\mathbf{a}}$ & $\mathbf{M}$ & $\mathbf{T}$ & & $\mathbf{B}$ & $\mathbf{M}$ & $\mathbf{T}$ \\
\hline 20 & $9 / 150^{\mathrm{b}}$ & $3 / 150$ & $0 / 100$ & & $3 / 32$ & & $2 / 32$ & $0 / 32$ \\
45 & $33 / 132$ & $3 / 132$ & $0 / 82$ & & $13 / 96$ & & $8 / 96$ & $4 / 64$ \\
$75^{\mathrm{c}}$ & $57 / 137$ & $5 / 137$ & $0 / 137$ & & $17 / 96$ & & $9 / 96$ & $6 / 96$ \\
120 & $64 / 137$ & $5 / 137$ & $0 / 137$ & & $28 / 64$ & & $10 / 64$ & $6 / 64$ \\
\hline
\end{tabular}

${ }^{\mathrm{a}}$ Leaves from bottom (B), middle (M), or top (T) of branch.

${ }^{\mathrm{b}}$ Number of plants positive in leaves by DAS-ELISA/number of tested plants.

${ }^{c}$ Plants were pruned following 75 dpi analyses, and new flush was assayed at $120 \mathrm{dpi}$.

Table 3. Distribution of Hibiscus latent Fort Pierce virus in infected Pink Versicolor and Brilliant Red hibiscus plants grown at different locations at defined days postinoculation (dpi) as determined by double antibody sandwich enzyme-linked immunosorbent assay (DAS-ELISA)

\begin{tabular}{|c|c|c|c|c|c|}
\hline \multirow{3}{*}{$\begin{array}{l}\text { Cultivar } \\
\text { Location }\end{array}$} & \multirow[b]{3}{*}{ dpi } & \multicolumn{4}{|c|}{ Tissue } \\
\hline & & \multicolumn{3}{|c|}{ Leaf position } & \multirow[b]{2}{*}{ Bark } \\
\hline & & $\mathbf{B}^{\mathbf{a}}$ & $\mathbf{M}$ & $\mathbf{T}$ & \\
\hline \multicolumn{6}{|l|}{ Pink Versicolor } \\
\hline Greenhouse & 210 & $5 / 30^{\mathrm{b}}$ & $0 / 30$ & $0 / 30$ & $30 / 30$ \\
\hline Growth Chamber & & $5 / 30$ & $6 / 30$ & $0 / 30$ & $30 / 30$ \\
\hline Greenhouse & 290 & $7 / 30$ & $1 / 30$ & $0 / 30$ & $30 / 30$ \\
\hline Growth Chamber & & $10 / 30$ & $6 / 30$ & $0 / 30$ & $30 / 30$ \\
\hline Field & & $1 / 16$ & $0 / 16$ & $0 / 16$ & $16 / 16$ \\
\hline \multicolumn{6}{|l|}{ Brilliant Red } \\
\hline Greenhouse & 160 & $3 / 16$ & $1 / 16$ & $16 / 16$ & $16 / 16$ \\
\hline Growth Chamber & & $7 / 17$ & $2 / 17$ & $17 / 17$ & $17 / 17$ \\
\hline Greenhouse & 210 & $5 / 16$ & $7 / 16$ & $16 / 16$ & $16 / 16$ \\
\hline Growth Chamber & & $17 / 17$ & $17 / 17$ & $17 / 17$ & $17 / 17$ \\
\hline Field & & $13 / 13$ & $13 / 13$ & $13 / 13$ & $13 / 13$ \\
\hline
\end{tabular}

${ }^{a}$ Leaves from bottom (B), middle (M), or top (T) of branch.

${ }^{\mathrm{b}}$ Number of plants positive by DAS-ELISA/number of inoculated plants.
Brilliant Red) and field-grown (Brilliant Red) plants than in greenhouse-grown plants. This was especially noticeable in Brilliant Red after pruning and the subsequent analysis at $210 \mathrm{dpi}$, when the virus was detected in all leaves along branches of all growth chamber- and field-grown plants. Less than half $(7 / 16)$ of the greenhouse-grown Brilliant Red plants had detectable virus in all leaves. The same trend was observed in Pink Versicolor plants, although overall virus distribution was more restricted as seen in prior experiments. Virus was detected in more middle leaves of growth chamber-grown Pink Versicolor plants than in greenhousegrown plants. No virus was detected in the top leaves of any Pink Versicolor plants grown under any condition. Curiously, virus spread into leaves was most restricted in the field-grown Pink Versicolor plants, where only one plant had detectable virus in its (bottom) leaves. Although virus was not distributed in every leaf on every plant of either cultivar, all plants of both cultivars were systemically infected since virus was consistently detected in their bark.

Virus detection. Leaf samples of individual plants from both cultivars were divided into three subsamples and tested by DAS-ELISA, TBIA, and IC-RT-PCR to determine if the limited systemic distribution of HLFPV in Pink Versicolor was a consequence of a low virus concentration in this cultivar, potentially below the DASELISA detection limit. DAS-ELISA and TBIA detected virus in only the bottommost leaf (leaf number 1) of several Pink Versicolor plants (a representative plant is shown in Fig. 1A and B) but in all leaves (leaf numbers 1 through 9) of several Brilliant Red plants (a representative plant is shown in Fig. 2A and B). However, IC-RTPCR detected viral RNA in leaf numbers 1 through 3 of a Pink Versicolor plant (Fig. 1C), demonstrating that HLFPV was present in several leaves above the single position detected by DAS-ELISA and TBIA. IC-RT-PCR revealed the presence of viral RNA in all leaves of a Brilliant Red plant (Fig. 2C), consistent with DASELISA and TBIA analysis.

Since HLFPV was always detected in bark samples from both cultivars by DASELISA, tissue prints were made of branch cross sections to localize the virus. TBIA analysis of stem sections from both cultivars revealed that the virus was detectable only in the cambium (data not shown). Brilliant Red stems contained a higher relative amount of viral coat protein based on the intensity of the colorimetric reaction.

Sanitation. Brief rinsing of contaminated scalpels with the chemicals used in the first experiment reduced but did not eliminate infection (Table 4). Overall, in the first experiment, 17 of 44 plants cut with contaminated and treated scalpels became infected. 
In the second experiment, the treatment of contaminated scalpels was increased to 1 min with increased concentrations of the chemicals used in the first experiment, additional chemicals, or heat. All plants cut with contaminated scalpels treated with $10 \%(\mathrm{wt} / \mathrm{vol}) \mathrm{NaOCl}$ or $20 \%(\mathrm{wt} / \mathrm{vol})$ NFDM remained virus free. One or two plants cut with contaminated scalpels treated with $20 \% \quad(\mathrm{wt} / \mathrm{vol})$ TSP, $5 \%$ (wt/vol) $\mathrm{NaOH}, 90 \%$ (vol/vol) ethanol, or flame became infected.

No infection occurred when plants were cut with sterile scalpels. Thirteen of 15 control plants (from both experiments) became infected after being cut with contaminated but untreated scalpels. The tap water wash of contaminated scalpels was not effective for tool sanitation, as 12 of 15 plants cut with these scalpels became infected.

\section{DISCUSSION}

All inoculation methods tested (rub, slash, and cut) proved reliable and were able to transmit the virus to plants of Pink Versicolor and Brilliant Red hibiscus. Slash-inoculation yielded the highest rates of virus transmission to both cultivars, perhaps due to the relatively higher amount of inoculum (four slashes per plant) applied directly into the vascular tissues of the plants. HLFPV was also readily transmitted to plants of both cultivars by a single cut (cut-inoculation procedure), suggesting that pruning is a likely means of virus spread. Additionally, $60 \%$ of the cuttings produced from excised Pink Versicolor stem tips showed virus presence after root formation, indicating that the virus was stable and remained infectious after dipping the cuttings in rooting hormones. Thus, transmission by cutinoculation can lead to infection of stock plants and cuttings during propagation, and landscape and nursery plants during pruning, and is likely responsible for the high level of virus incidence $(56 \%)$ in Florida landscape plants found in a preliminary virus survey (1). Knife-slash inoculation has been previously reported as an effective method for transmission of several viruses including ToRSV, Citrus tristeza virus, and also Citrus exocortis viroid $(3,9,10)$. According to Hu et al. (14), the easy mechanical transmission of Cymbidium mosaic virus (CymMV) and Odontoglossum ringspot virus during plant repotting, flower sprays, and flower harvesting was one of the main reasons for their widespread occurrence in Hawaiian nurseries.

The results obtained in time course analyses revealed that in the early stages of virus infection (10 and $20 \mathrm{dpi}$ ), HLFPV followed the same pathway of movement and distribution in both cultivars: from the place of primary infection (inoculated leaves, slashes, or cuts) downward to the roots. Similar patterns of movement from the inoculated leaves to the roots have been reported for CymMV in orchids (14), Cherry leaf roll virus (CLRV) in tobacco (19), and ACLSV in peach (4). In contrast, translocation of PNRSV first to the shoots and after that toward the roots of infected apricot has been observed (4), and movement and distribution only upward from the inoculation point of ToRSV in infected grape was reported (23).

A difference in virus distribution between leaves of Pink Versicolor and Brilliant Red plants was noted later at 45, 75, 120, and 210 dpi. Virus was distributed throughout all leaves along the branches of most Brilliant Red plants at 210 dpi. In contrast, virus was restricted almost entirely to the bottom (oldest) leaves of Pink Versicolor plants. Only 9\% of Pink Versicolor plants contained detectable virus in the middle leaves at the end of analysis (1 year), and no plants were ever found to contain detectable virus in the top (youngest) leaves. The application of DASELISA, TBIA, and IC-RT-PCR methods in parallel to the same Pink Versicolor samples confirmed the limited distribution of

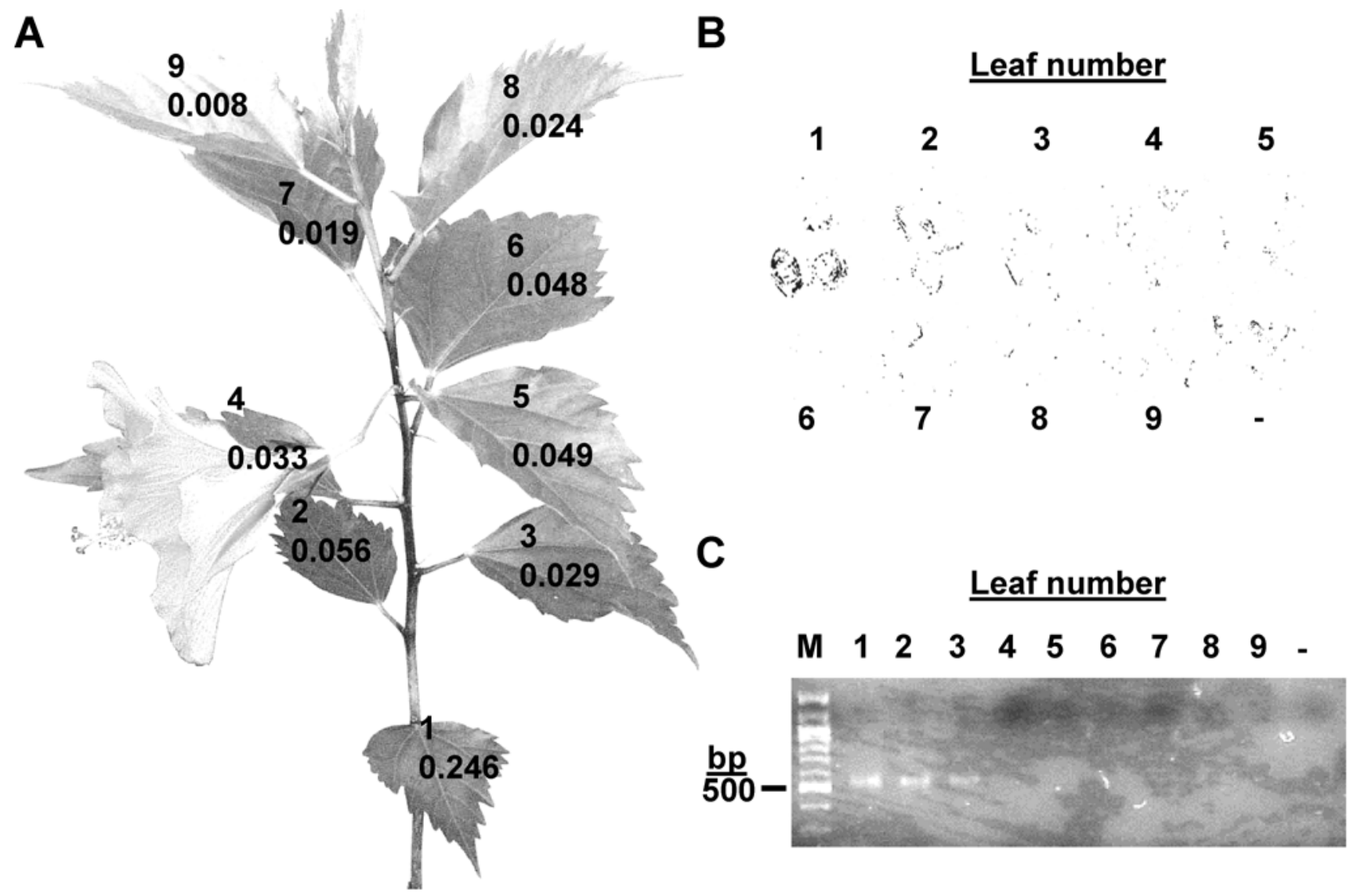

Fig. 1. Distribution of Hibiscus latent Fort Pierce virus in a Pink Versicolor hibiscus plant determined by A, double antibody sandwich enzyme-linked immunosorbent assay, $\mathbf{B}$, tissue blot immunoassay, and $\mathbf{C}$, immunocapture-reverse transcription-polymerase chain reaction. Each leaf (A) is numbered (1 to 9) from bottom to top of branch and is shown with mean absorbance values at $A_{405 \mathrm{~nm}}$. Leaf position numbering is continued in (B) and (C). A negative control $(-)$ leaf from an uninfected hibiscus plant is included in (B) and (C), and markers (M) with size in base pairs (bp) are shown on the left of the gel in (C). 
HLFPV in this cultivar. Although the reasons for restricted distribution of HLFPV in Pink Versicolor are not yet known, several precedents for this phenomenon exist. For instance, a restricted and uneven virus distribution has been reported for ACLSV and PNRSV (4). The translocation of these two viruses has been shown to be more dependent on the fruit tree species than the virus, since both viruses were more readily spread within peach than within apricot trees (4). Differences in the support of long-distance movement of TMV by various plant genera and species have also been reported (13), and cultivar-specific dependence of long-distance movement has been shown for Cucumber mosaic virus in pepper (6) and Cowpea chlorotic mottle virus in soybeans (12). The final distribution of a virus in infected plants is a process dependent on several factors, including host genes, viral genes, the host defense system, and environmental factors, all of which affect the rate and extent of virus movement through the plant (15). As discussed by Carrington et al. (5), virus movement in plants requires compatibility between virus-encoded movement factors and host components.
Environmental conditions, especially temperature, can influence the disease process in virus-infected plants (15). Our results with greenhouse-, growth chamber-, and field-grown hibiscus plants demonstrate that HLFPV spreads more quickly in both cultivars under growth chamber conditions, and in Brilliant Red also under field conditions (Table 3). This observation likely reflects the temperature differences between the three growth conditions examined $\left(30,20\right.$, and $16^{\circ} \mathrm{C}$ for greenhouse,

Table 4. Sanitation treatments for management of Hibiscus latent Fort Pierce virus in hibiscus

\begin{tabular}{lcc}
\hline Treatment & $\begin{array}{c}\text { Contaminated tool } \\
\text { used immediately }\end{array}$ & $\begin{array}{c}\text { Contaminated tool } \\
\text { treated for 1 min }\end{array}$ \\
\hline $3 \% \mathrm{NaOCl}^{\mathrm{b}}$ & $3 / 7^{\mathrm{c}}$ & $\ldots$ \\
$6 \% \mathrm{NaOCl}$ & $1 / 7$ & $\ldots$ \\
$10 \% \mathrm{NaOCl}$ & $\ldots$ & $0 / 28$ \\
$10 \% \mathrm{TSP}$ & $6 / 8$ & $\ldots$ \\
$20 \% \mathrm{TSP}$ & $3 / 8$ & $1 / 28$ \\
$1 \% \mathrm{NaOH}$ & $2 / 7$ & $\ldots$ \\
$2 \% \mathrm{NaOH}$ & $2 / 7$ & $\ldots$ \\
$5 \% \mathrm{NaOH}$ & $\ldots$ & $1 / 15$ \\
$20 \% \mathrm{NFDM}$ & $\ldots$ & $0 / 15$ \\
$90 \% \mathrm{Ethanol}$ & $\ldots$ & $1 / 15$ \\
Flame & $\ldots$ & $2 / 27$ \\
Uncontaminated & $0 / 5$ & $\ldots$ \\
Contaminated-untreated & $4 / 5$ & $9 / 10$ \\
Tap water & $\ldots$ & $12 / 15$ \\
\hline
\end{tabular}

a Partially purified virus preparation at a concentration of $2 \mu \mathrm{g} / \mathrm{ml}$ was used for tool contamination.

${ }^{\mathrm{b}} \mathrm{NaOCl}=$ sodium hypochlorite; $\mathrm{TSP}=$ trisodium phosphate; $\mathrm{NaOH}=$ sodium hydroxide; $\mathrm{NFDM}=$ nonfat dry milk.

${ }^{c}$ Number of infected plants as determined by double antibody sandwich enzyme-linked immunosorbent assay/total number of inoculated Pink Versicolor plants.

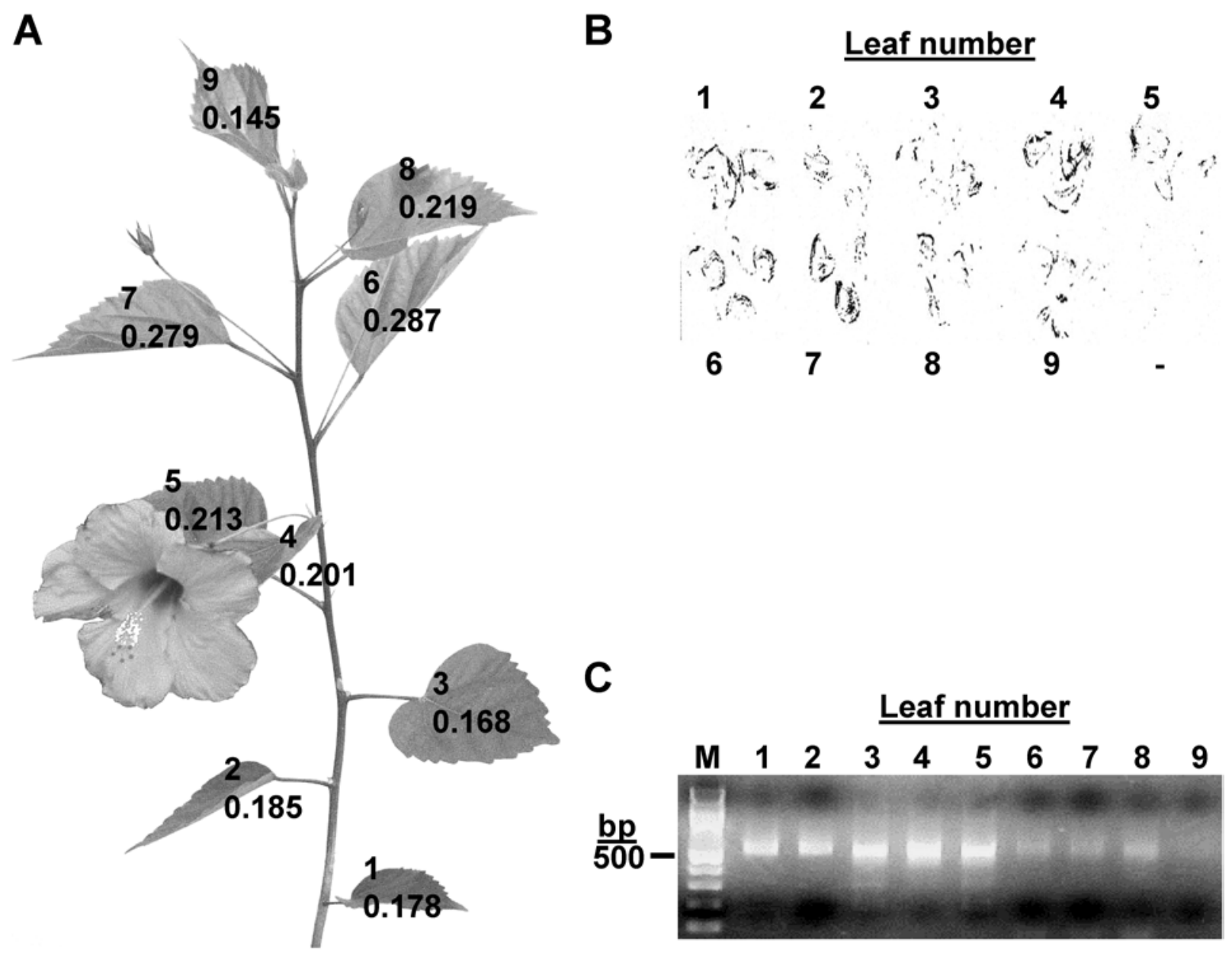

Fig. 2. Distribution of Hibiscus latent Fort Pierce virus in a Brilliant Red hibiscus plant determined by A, double antibody sandwich enzyme-linked immunosorbent assay, $\mathbf{B}$, tissue blot immunoassay, and $\mathbf{C}$, immunocapture-reverse transcription-polymerase chain reaction. Each leaf (A) is numbered (1 to 9 ) from bottom to top of branch and is shown with mean absorbance values at $A_{405 \mathrm{~nm}}$. Leaf position numbering is continued in (B) and (C). A negative control (-) leaf from an uninfected hibiscus plant is included in (B), and markers (M) with size in base pairs (bp) are shown on the left of the gel in (C). 
growth chamber, and field, respectively). However, since there is not a perfect correlation between lower temperature and greater virus spread (e.g., the most limited virus distribution in Pink Versicolor plants was observed under field conditions), differences in light condition and humidity may also be responsible. In general, none of the environmental conditions tested altered the overall pattern of virus distribution, which was always observed to be most restricted in Pink Versicolor plants.

Since hibiscus plants from both cultivars were infected successfully by cutinoculation, some precautions are advisable to avoid mechanical transmission during plant propagation and pruning. Based on our results, the precautions selected should consider both the treatment used for sanitation and also the length of treatment (i.e., at least $1 \mathrm{~min}$ ). No infection occurred after treatment of the pruning tools for $1 \mathrm{~min}$ with $10 \%$ (wt/vol) $\mathrm{NaOCl}$ or $20 \%(\mathrm{wt} / \mathrm{vol}) \mathrm{NFDM}$, and we suggest these treatments for use in everyday horticultural operations to eliminate HLFPV. It is also likely that with longer treatment times, 3 and $6 \%$ (vol/vol) $\mathrm{NaOCl}, 2 \%$ (wt/vol) $\mathrm{NaOH}, 20 \%$ (wt/vol) TSP, and flame may be effective. We note also that all materials for these treatments are readily available and easily applied, unlike some previously tested treatments, which included $\mathrm{NaOH}$ and formaldehyde $(8,14,18,24)$.

Recognition that HLFPV can be distributed and transmitted both by the use of cuttings from infected plants during plant propagation and by contaminated tools during pruning procedures has a practical significance to hibiscus nurseries, growers, and landscape maintenance workers, as common horticultural practices are likely means of virus dissemination and spread in the environment. In addition, the observation of restricted virus distribution and low virus concentration in one of the cultivars assayed provides guidance for sampling to better detect the virus in routine stock plant indexing and virus management.

\section{ACKNOWLEDGMENTS}

We thank Carrie Vanderspool, Heather Capobianco, Reid Lewis, and Karen Cerveny for their excellent technical assistance, Brad Reddick for providing culture virus indexed hibiscus cuttings, and Mark E. Hilf and Dennis J. Lewandowski for valuable discussion and critical reviews of the manuscript.

\section{LITERATURE CITED}

1. Adkins, S., Kamenova, I., Achor, D., and Lewandowski, D. J. 2003. Biological and molecular characterization of a novel tobamovirus with a unique host range. Plant Dis. 87:11901196.

2. Bitterlin, M. W. 1984. Distribution of tomato ringspot virus in apple trees. Plant Dis. 68:567-571.

3. Bitterlin, M. W., Gonsalves, D., and Scorza, R. 1987. Improved mechanical transmission of tomato ringspot virus to Prunus seedlings. Phytopathology 77:560-563.

4. Cambra, M., Llacer, G., Aramburu, J., and Lavina, A. 1986. Translocation of chlorotic leaf spot and prunus ringspot viruses in apricot and peach seedlings. Acta Hortic. 193:233-240.

5. Carrington, J. C., Kasschau, K. D., Mahajan, S. K., and Schaad, M. C. 1996. Cell-to-cell and long-distance transport of viruses in plants. Plant Cell 8:1669-1681.

6. Dufour, O., Palloix, A., Selassie, K. G., Pochard, E., and Marchoux, G. 1989. The distribution of cucumber mosaic virus in resistant and susceptible plants of pepper. Can. J. Bot. 67:655-660.

7. Fridlund, P. R. 1982. Distribution of chlorotic leaf spot virus infected buds on various lengths of apple budsticks in successive years. Acta Hortic. 130:85-88.

8. Garnsey, S. M. 1967. Contaminated tools can spread exocortis virus of citrus. Proc. Florida State Hortic. Soc., 1967. 80:69-73.

9. Garnsey, S. M., Gonsalves, D., and Purcifull, D. E. 1977. Mechanical transmission of citrus tristeza virus. Phytopathology 67:965-968.

10. Garnsey, S. M., and Whidden, R. 1973. Efficiency of mechanical inoculation procedure for citrus exocortis virus. Plant Dis. Rep. 57:886889.
11. Gonsalves, D. 1981. Detection of tomato ringspot virus in grapevines: Irregular distribution of virus. Pages 95-106 in: Proc. Int. Counc. Study Viruses and Virus Dis. Grapevines (ICVG), 7th. Agriculture Canada.

12. Goodrick, B. J., Kuhn, C. W., and Hussey, R. S. 1991. Restricted systemic movement of cowpea chlorotic mottle virus in soybean with nonnecrotic resistance. Phytopathology 81: 1426-1431.

13. Holmes, F. O. 1946. A comparison of the experimental host ranges of tobacco etch and tobacco mosaic viruses. Phytopathology 36:643-659.

14. Hu, J. S., Ferreira, S., Xu, M. Q., Lu, M., Iha, M., Pflum, E., and Wang, M. 1994. Transmission, movement, and inactivation of cymbidium mosaic and odontoglossum ringspot viruses. Plant Dis. 78:633-636.

15. Hull, R. 2002. Matthews' Plant Virology. 4th ed. Academic Press, San Diego. p. 403.

16. Kamenova, I., and Adkins, S. 2004. Comparison of detection methods for a novel tobamovirus isolated from Florida hibiscus. Plant Dis. 88:34-40.

17. Lawson, R. H. 1995. Virus and Virus-like Diseases of Bulb and Flower Crops. G. Loebenstein, R. H. Lawson, and A. A. Brunt, eds. John Wiley \& Sons, Chichester. pp. 476-481.

18. Lawson, R. H., and Brannigan, M. 1986. Virus disease of orchids. Pages 2-49 in: Handbook of Orchid Pests and Diseases. American Orchid Society, West Palm Beach, Fl.

19. Mas, P., and Pallas, V. 1996. Long-distance movement of cherry leaf roll virus in infected tobacco plants. J. Gen. Virol. 77:531-540.

20. Morvan, G., and Castelain, C. 1976. Localization of sharka virus in peach trees in reference to sanitary checking. Int. Sympos. Fruit Tree Virus Dis., 10th. Mitt. Biol. Bundesanst. LandForstwirtsch. Berl.-Dhlem. 170:57-63.

21. Samuel, G. 1934. The movement of tobacco mosaic virus within the plant. Ann. Appl. Biol. 21:90-111.

22. Timmer, L. W., and Garnsey, S. M. 1979. Variation in the distribution of citrus ring spot and psorosis viruses within citrus hosts. Phytopathology 69:200-203.

23. Uyemoto, J. K., and Gilmer, R. M. 1972. Spread of tomato ring spot virus in "Baco Noir" grapevine in New York. Plant Dis. Rep. 56:1062-1064.

24. Wisler, G. C. 1989. How to Control Orchid Viruses: The Complete Guidebook. Maupin House Publishers, Gainesville, FL. 